Article

\title{
Premiums for Non-Sustainable and Sustainable Components of Market Volatility: Evidence from the Korean Stock Market
}

\author{
Thuy Thi Thu Truong and Jungmu Kim * (1) \\ Department of Business Administration, School of Business, Yeungnam University, Gyeongsan 38541, Korea; \\ thuytruong@ynu.ac.kr \\ * Correspondence: jungmu@yu.ac.kr
}

Received: 8 August 2019; Accepted: 11 September 2019; Published: 19 September 2019

\begin{abstract}
The study investigates the premiums expected for non-sustainable and sustainable components of market volatility in Korea during the August 1991 to December 2018 period. We decompose market volatility into non-sustainable and sustainable components and construct the factors that mimic the two respective components of market volatility. The portfolio analysis and Fama-MacBeth regressions reveal that both short- and long-term components are negative pricing factors in the Korean stock market. Specifically, stocks with higher sensitivities to the long-term volatility factor have lower average annual returns by approximately $14 \%$, than stocks with lower sensitivities. This implies that stocks with high sensitivity to sustainable volatility provide a hedging opportunity against future uncertainty, and thus, investors are willing to pay an annual premium of $14 \%$ for such stocks. Our results are robust to variations in samples and methods.
\end{abstract}

Keywords: Korean market; market risk; pricing factor; stock returns; sustainable volatility

\section{Introduction}

Classical finance theories argue that investors dislike taking market risk and expect a positive premium for it. For example, the capital asset pricing model [1,2] predicts that investors will expect a higher return on stocks with higher market risk, as measured by the loading to market volatility or market beta. However, several empirical studies have provided somewhat controversial results. In contrast to the capital asset pricing model's prediction, Ang et al. [3] find that investors require a negative premium for market volatility, and Frazzini and Pedersen [4] suggest a betting-against-beta strategy that exploits the anomaly of low-beta stocks having higher returns. Therefore, the role of market risk or market volatility in explaining stock returns is still unclear and worthy of investigation.

Recent studies on market volatility [5-18] have argued that market volatility is affected by two factors, a short-term (or volatile) component of volatility and a long-term (or sustainable) component of volatility; however, it is difficult to clearly explain the economic significance of each factor. Although there are several studies that have affirmed the pricing of two volatility components in the cross-section of stock returns in developed markets, relatively little literature has identified and examined these two factors separately in emerging markets, especially in the context of the Korean market, the leading financial market among emerging economies.

The quantitative analysis of the Korean market becomes more important and valuable. The Morgan Stanley Capital International (MSCI) Emerging Markets Index still classifies Korea as an emerging market. However, the Financial Times Stock Exchange (FTSE) index and the Standard \& Poor's Financial Services LLC (S\&P) reclassify Korea to a developed market from an emerging market due to its rapid growth. It seems that Korea is a case somewhere between emerging and developed countries. 
Hence, Korea is a special case; its stock market may behave differently than what is usually seen in either developed or emerging markets. The growth of the Korean economy is described as the Miracle on the Han River, which has brought Korea to the ranks of countries in the Organization for Economic Cooperation and Development (OECD) and the G-20. Moreover, the economy of Korea is dominated by family-run conglomerates called chaebols, unique business structures that exist only in the Korean market. "Chaebol" families, often only care about their personal interests and ignore the interests of their shareholders. The existence of chaebols affects the stock price of Korean firms, thereby affecting market volatility in the Korean stock market [19]. These important characteristics make its analysis interesting and meaningful for researchers, policy makers, and market practitioners. It is necessary to research the Korean market independently from other markets. Therefore, we focus on the Korea financial market in this study.

Our study goes one step further. We extract sustainable volatility from the total market volatility by decomposing it into short-term (i.e., non-sustainable) and long-term (i.e., sustainable) components. We define sustainable volatility as the market volatility component that has more persistent behavior than the short-term component and focuses on analyzing its effect on stock returns. The sustainable (non-sustainable) component and long-term (short-term) component are interchangeably used throughout this paper. With this setting, we address two research questions. Firstly, we examine if the sustainable volatility component is priced in the Korean stock market. Secondly, we explore how much investors are willing to pay, if any, as premium for taking sustainable volatility. We find evidence that the sustainable volatility component is priced in the stock market. Moreover, the result shows that stocks with higher sensitivity to the sustainable volatility component have lower returns. Similar to controversial findings, such as those of Ang et al. [3] and Frazzini and Pedersen [4], our result runs counter to the classical asset pricing models' prediction. However, in the intertemporal capital-asset-pricing-model framework [20], our finding implies that investors are willing to pay an insurance premium because stocks with high sensitivity to sustainable volatility offer a hedging opportunity against future uncertainty and are attractive despite low returns.

The empirical findings and our methodology can be summarized as follows. Firstly, we investigate the contemporaneous relation between the two volatility components and the average stock returns by forming portfolios that are sorted with reference to loadings on short-and long-term volatility innovations. The results show that portfolios with low (high) loadings on both short- and long-term volatility innovations earn high (low) average excess stock returns. Specifically, firms with higher sensitivities to innovation in volatility in the long term (short term) reduce average returns by approximately $14 \%$ (13.85\%). Secondly, we examine the explanatory power of the volatility components in the cross-section of stock returns, simultaneously controlling for other cross-sectional factors (such as value and size factors) by using Fama-MacBeth two-stage regressions [21]. The results confirm that both short- and long-term volatility components are priced in the Korean stock market. Moreover, the risk-pricing for both volatility components are significantly negative, after controlling for three factors of the Fama-French model [22], implying that investors in the Korean stock market are willing to pay a premium against increases in volatility risk. In summary, the empirical results of our study signify that short- and long-term volatility components affect the cross-section of stock returns.

Our study contributes to the literature in two aspects. Firstly, we quantify the premium for sustainable volatility by suggesting methods for estimating the sustainable volatility component and constructing the factor that mimics the component. This is a methodological contribution. Secondly, we present evidence that volatility is negatively priced in the stock market-a belief that has long been controversial, since this finding is opposite to the prediction of the classical theory.

The remainder of this paper is structured as follows. Section 2 reviews the related literature. Section 3 describes the data and methodology used to estimate the short- and long-term volatility components and presents the portfolio analysis method used to examine the cross-sectional relationship between market volatility components and stock returns. Fama-MacBeth two-stage regressions are carried out to further examine the pricing of the two volatility components in the Korean stock market, 
controlling for other cross-sectional effects. The results are interpreted and discussed in Section 4 . Robustness checks are provided in Section 5. Finally, Section 6 offers our conclusions.

\section{Literature Review}

The assessment of stock volatility has attracted increasing attention among academic researchers. Market stock volatility is associated with future investment opportunities for firms. Market volatility can affect the value of a firm's shares. Therefore, firms respond by raising more capital by issuing shares or by using their stocks as leverage to buy firms or acquire competitors. It is believed that investors, financial analysts, and portfolio managers are aware of the volatility in stock investment. Previous researchers have proposed various measures of volatility. Altman and Schwartz [23] define the uncertainty of stock price movement as a volatility measure. Pinches and Kinney [24] also employ basic historical volatility measure (i.e. daily standard deviation of stock returns). In addition, volatility is measured by implied volatility presented in an option pricing model $[25,26]$. Volatility cannot be observed directly; thus, it is necessary to employ a reasonable proxy for it when conducting financial studies.

Researchers have continuously discussed and argued about the relation between an asset's volatility and its return. French et al. [27] use the Autoregressive Conditional Heteroskedasticity in Mean (ARCH-M) model of Engle et al. [28] and find a positive relation between expected return and stock market volatility in the U.S. stock market from January 1928 to December 1984. Goyal and Saretto [29], based on the U.S. equity option market data from 1996 to 2005, show that the volatility risk premium, the difference between individual implied volatility and historical volatility, is positively related to option returns. A positive relation between returns and volatility is also observed by subsequent researchers [30-34]. By contrast, other studies show a negative relation or insignificant estimates [35-39]. For example, Glosten et al. [39] observe a negative relationship between returns and stock volatility during 1951 to 1989 by using the modified Generalized Autoregressive Conditional Heteroskedasticity in Mean (GARCH-M) model. More recently, Ang et al. [3] have found that innovation in market volatility has a negative risk price of approximately $-1 \%$ per annum for a sample of the U.S. market from 1986 to 2000 by using the Chicago Board Options Exchange Volatility Index as a proxy for market volatility. Da and Schaumburg [40] use a sample of the U.S. market to examine the pricing of volatility across asset classes. They find that market-volatility factor can price different assets such as portfolios of stocks, stock options, and corporate bonds. Consistent with the previous study, significant negative volatility risk premiums are observed in the stock and option markets, with the premium for corporate bonds also negative but not significant because corporate bond returns were volatile during the period covered. However, the magnitude of the risk premium is similar across different assets, thereby supporting the contention that the market volatility is a pricing factor in asset pricing model. The results of Cremers et al. [41] in the U.S. market between 1988 and 2011 also show that volatility risk factor is negatively priced in the cross-section of stock returns. This relationship is examined in the context of the BRIICKS (Brazil, Russia, India, Indonesia, China, South Korea, and South Africa) economies by Sehgal and Garg [42]. They find low premiums for portfolios with high market volatility in Brazil, South Korea, and Russia. However, significantly positive risk premiums are found for Indonesia and South Africa. In India and China, no significant risk premiums are reported. With a sample of 17 international stock markets from December 1992 to December 2007, Dimitriou and Simos [43] find a significantly negative relationship between stock volatility and expected returns in most markets, except Austria, Belgium, and Luxemburg by using a semiparametric specification for the conditional variance. Using the GARCH-M model in four of China's stock exchanges, Lee et al. [44] find no evidence of a relationship between volatility and expected return. In the context of emerging financial markets, De Santis and Imrohoroğlu [45] do not find any relation between expected stock returns and volatility in each country. However, they detect a risk-reward relation in the Latin American markets when they generalize their model and assume international integration. Using GARCH in the mean estimations, Shin [46] find a positive but 
insignificant relation between expected stock returns and volatility in emerging markets. Chiang and Doong [47] find significant relationships between stock volatility and returns in four out of the seven Asian stock markets by following the method suggested by French et al. [27]. In summary, the role of market volatility factor in asset pricing test remains controversial.

A better approach than the one-factor model for market return volatility is the two-component volatility specification [5-12]. For instance, Alizadeh et al. [7] identify two factors in the volatility models. Specifically, they argue that there are two factors, one highly persistent and slowly moving, the other rapidly moving. The two-factor stochastic volatility models are also investigated in the option pricing literature [13,48,49]. For example, for the valuation of European options, Christoffersen et al. [13] present a new model with two long- and short-term components of the volatility of returns. In the Hong Kong stock market, Ané [14] suggests that a model including short- and long-term volatility components significantly improves the goodness-of-fit over the traditional single model. Adrian and Rosenberg [15] also decompose market volatility into short- and long-term components to further support the relationship between returns and volatility. Based on U.S. stock market data from 1963 to 2005 , they find that both volatility components have significantly negative risk prices. Specifically, the short-term volatility has a risk price of $-2.25 \%$ per annum, and the long-term volatility has a risk price of $-24.24 \%$ per annum. Yang and Copeland [16] also apply the decomposition of market volatility to the UK stock market to examine whether the short- and long-term volatilities are priced in the cross-section of stock returns and to estimate the prices of these components. Their study asserts that the short- and long-term volatility components are also negatively priced. By contrast, using the two-component model, Guo and Neely [17] confirm a positive relationship between volatility risk and returns based on international stock market data from 1974 to 2003. Zhu [18] decompose volatility into a volatile component and a persistent component to examine the relation between volatility and returns. By analyzing data from 10 Asia-Pacific stock markets-eight Asian and two Oceanian stock markets-the volatile component is found to have a significant positive relation with returns. By contrast, the persistent component is not significantly priced in the respective stock markets.

Based on this stream of literature, two components of market volatility can be priced in the cross-section of stock returns. Therefore, this study examines the pricing of two components of market volatility risk in the Korean stock market to fill the gap in the literature. We decompose market volatility into short- and long-term volatility based on the model specification suggested by Adrian and Rosenberg [15]. However, our study differs from Adrian and Rosenberg [15] in measuring innovations of the volatility components at a monthly frequency. We construct factors that mimic volatility-component innovations, similar to the method used by Ang et al. [3], instead of summing innovations over the days of each month.

\section{Data and Methodology}

\subsection{Data}

All the Korea Composite Stock Price Index (KOSPI) and the Korean Securities Dealers Automated Quotations (KOSDAQ) stock data come from DataGuide. Based on data availability, the sample period for the daily and monthly data runs from 1 August 1991 to 28 December 2018. We exclude the daily data information of 15 days before the delisting date of a firm. We also exclude stocks with closing prices below KRW 1000. Additionally, all returns of stocks are "winsorized" at the 1\% and 99\% levels to minimize the effects of potential outliers. In other words, we use the 99th percentile value to replace any value of return greater than the 99th percentile of all values of return and the 1st percentile value to replace any value below the 1st percentile of all values of return for each month. Our dataset has 527,414 firm-month observations on 3090 firms. The rate of the 91-day certificate of deposit is chosen as the risk-free rate. 


\subsection{Volatilities Components}

\subsubsection{Volatility Decomposition}

To decompose market volatility components, we use the model specification suggested by Adrian and Rosenberg [15]. First, we define the market excess return process as follows:

$$
R_{t+1}=\theta_{1}+\theta_{2} s_{t}+\theta_{3} l_{t}+\sqrt{v_{t}} \varepsilon_{t+1}
$$

where $R_{t}$ is daily excess market return computed by value-weighting the return of all stocks in excess of the risk-free rate, and $v_{t}$ is the market variance determined by the short-term volatility $s_{t}$ and the long-term volatility $l_{t}$ in a manner of $v_{t}=e^{2\left(s_{t}+l_{t}\right)}$. Next, we assume that the two volatility components follow the dynamics of:

$$
s_{t+1}=\theta_{4} s_{t}+\theta_{5} \varepsilon_{t+1}+\theta_{6}\left(\left|\varepsilon_{t+1}\right|-\sqrt{2 / \pi}\right)
$$

and

$$
l_{t+1}=\theta_{7}+\theta_{8} l_{t}+\theta_{9} \varepsilon_{t+1}+\theta_{10}\left(\left|\varepsilon_{t+1}\right|-\sqrt{2 / \pi}\right) .
$$

We observe daily time-series of the excess market returns $R=\left\{R_{1}, R_{2}, \ldots, R_{T}\right\}$. With this input data, we estimate 10 model parameters and the initial values of the short- and long-term volatility components, that is, $\Theta=\left\{\theta_{1}, \theta_{2}, \ldots, \theta_{10}\right\}$. To estimate the parameters, we use the maximum likelihood method. With the assumption that $\varepsilon_{t}$ is the standard normal distribution, it is straightforward to derive the log-likelihood of the model specification. Once we estimate these values, we can compute the daily time-series of the two volatility factors, i.e., $s=\left\{s_{1}, s_{2}, \ldots, s_{T}\right\}$ and $l=\left\{l_{1}, l_{2}, \ldots, l_{T}\right\}$. We also compute the daily innovations of each volatility component based on the difference between the volatility component at date $t$ and its value 21 days earlier. Specifically, the short-term volatility innovation is sres $_{t}=s_{t}-E_{t-21}\left[s_{t}\right]$, and the long-term volatility innovation is $l r e s_{t}=l_{t}-E_{t-21}\left[l_{t}\right]$.

\subsubsection{Factors Mimicking Volatility Components}

To measure innovations of the volatility components at a monthly frequency, we construct factors that mimic volatility-component innovations, similar to the method Ang et al. [3] apply to market volatility. We denote these mimicking factors as Flres and Fsres. Innovations in the volatilities' components can be constructed at any frequency using Flres or Fsres. We simply cumulate daily returns over the month on the base assets used to create the monthly mimicking factors.

Following Ang et al. [3], we create the mimicking factors Flres and Fsres to track lres and sres by estimating the coefficient $b$ in the following regressions:

$$
\begin{aligned}
& \text { lres }_{t}=a+b_{\prime} X_{t}+u_{t}, \\
& \text { sres }_{t}=a+b_{\prime} X_{t}+u_{t},
\end{aligned}
$$

where $X_{t}$ represents the excess return on the base assets. $b X_{t}$ is the factor Flres (Fsres) that mimics lres (sres). We use five portfolios formed on the past $\beta_{\text {lres }}$ and five portfolios formed on the past $\beta_{\text {sres }}$ as the base assets $X_{t}$ in Equations (4) and (5), respectively. To estimate $\beta_{\text {lres }}\left(\beta_{\text {sres }}\right)$, we run daily time-series regressions of individual excess returns on long-term (short-term) volatility innovations, controlling for the Fama and French three-factor model [22], over each month. Portfolios are formed by sorting stocks based on past $\beta_{\text {lres }}$ or $\beta_{\text {sres }}$ that are estimated over the previous month. We then calculate the daily value-weighted average excess returns of the five portfolios used in both equations. We run daily regressions in Equations (4) and (5) for every month to estimate monthly $b$. Finally, we construct the monthly mimicking factor for the short- and long-term volatility innovations using the estimates of $b$ times the monthly excess returns of the five portfolios in both equations. 


\subsection{Portfolio Analysis}

The first goal of this study is to test whether stocks with different sensitivities to short- and long-term volatility innovations have different average returns. We use two factors, namely, the market factor and the Fsres (or Flres) in the model to measure sensitivity to the short-term (or long-term) volatility innovations. We do not directly control size and value factors in Equations (6) and (7) because controlling for other cross-sectional factors in forming portfolios may add a lot of noise (as Ang et al. [3] mentioned). Thus, we have:

$$
\begin{aligned}
& R_{t}^{i}=\alpha_{t}+\beta_{M K T}^{i} M K T_{t}+\beta_{\text {Fsres }^{i}}^{i} \text { Fres }_{t}+\varepsilon_{t^{\prime}}^{i} \\
& R_{t}^{i}=\alpha_{t}+\beta_{M K T}^{i} M K T_{t}+\beta_{\text {flres }}^{i} \text { Flres }_{t}+\varepsilon_{t}^{i}
\end{aligned}
$$

where $R_{t}^{i}$ is the return on stock $i$ in excess of the risk-free rate at month t. $\beta_{M K T}^{i}$ is the loading on the market factor. $M K T_{t}$ is the market return in excess of the risk-free rate at month t. $\beta_{\text {sres }}^{i}$ and $\beta_{\text {lres }}^{i}$ are the loadings on the short- and long-term volatility innovations on stock $i$, respectively. Fsres $t_{t}$ and Flres $s_{t}$ are the factors that mimic the short- and long-term volatility innovations at month $t$, respectively.

From $t$ to $t+12$, we run monthly time-series regressions of individual excess returns on the innovations of the short- and long-term volatilities, corresponding to Equations (6) and (7), to obtain cross-sectional loadings on the short- and long-term volatility innovations, respectively. The estimated values of these realized loadings are used to sort stocks into quintiles for the same 12-month period. The cross-sectional annual excess returns are calculated as cumulative returns from monthly excess returns during the 12-month period. After forming the portfolios, the equal-weighted average of the realized excess returns for each portfolio is computed over the same 12-month period. We also compute the average cross-sectional loadings on short-and long-term volatility innovations for each portfolio over the same 12-month period with average returns. Overlapping sample periods with a 12-month window and 1-month step are applied. For example, our sample period is from August 1991 to December 2018. Over the first period, from August 1991 to July 1992, we run monthly time-series regressions to obtain cross-sectional loadings on short-and long-term volatility innovations. These loadings are used to sort stocks into five portfolios. The 12-month-period excess returns of individual stocks are cumulated from monthly excess returns from August 1991 to July 1992. We then calculate average returns and get the average of these cross-sectional loadings for each portfolio. We repeat the same procedure for the next period from September 1991 to August 1992 and so on.

\subsection{Fama-MacBeth Regressions}

The second goal of this study is to estimate the prices of the short-and long-term volatility components, simultaneously controlling for other cross-sectional factors by running two-stage Fama-MacBeth regressions [21]. We use both the 25 portfolios and the individual stocks as base assets.

In the case where a portfolio is the base asset, stocks are initially sorted into 25 portfolios based on size and book-to-market equity. At the end of June of year T, portfolios are constructed based on the intersections of five portfolios formed on the KOSPI market equity (ME) and five formed on the ratio of KOSPI book-to-market equity (BE/ME). The KOSPI market equity is observed at the end of June of year T. BE/ME is the book equity for the last fiscal yearend in T-1 divided by the market equity for December of year T-1. Firms with negative BE/ME are excluded. The monthly equal- and value-weighted average excess returns on the 25 portfolios are calculated from July of year $\mathrm{T}$ to June of year $\mathrm{T}+1$. We then carry out two-stage Fama-MacBeth regressions. In the first stage, we run monthly time-series regressions of excess returns of 25 portfolios on factors such as the market factor, Small-Minus-Big (SMB), High-Minus-Low (HML), and short- and long-term volatility innovations to obtain cross-sectional factor loadings over the 12-month period as follows:

$$
R_{t}^{i}=\alpha_{i}+\beta_{M K T}^{i} M K T_{t}+\beta_{H M L}^{i} H M L_{t}+\beta_{S M B}^{i} S M B_{t}+\beta_{F X}^{i} F X_{t}+\varepsilon_{t}^{i}
$$


where $F X_{t}$ are the factors mimicking short- or long-term volatility innovations at month $t$. We also calculate the annual excess returns of 25 portfolios from the monthly excess returns of these 25 portfolios over the same 12-month period.

In the second stage, we run a cross-sectional regression of the excess returns of the 25 portfolios on loadings estimated above as follows:

$$
R_{i}=\lambda_{0}+\beta_{M K T}^{i} \lambda_{M K T}+\beta_{H M L}^{i} \lambda_{H M L}+\beta_{S M B}^{i} \lambda_{S M B}+\beta_{F X}^{i} \lambda_{F X}+\varepsilon_{i},
$$

where $R_{i}$ is the average return of portfolio i over the 12-month period.

We then repeat these two stages for other 12-month periods. We use overlapping method with a 12-month period window and a 1-month step. Finally, the factor premium $\lambda$ is calculated as the time-series average of estimates in Equation (9).

In the case where individual stocks are the base assets, we run monthly time-series regressions of the individual stocks' excess returns on the relevant factors to obtain cross-sectional factor loadings over the 12-month period. Afterwards, the cross-sectional excess returns of individual stocks are regressed on estimated loadings. These procedures are repeated for other 12-month periods, and we also calculate the time-series average of these estimates.

The Newey-West standard errors of coefficients [50] with 12 lags are reported to remedy the errors-in-variables problem resulting from the use of overlapping method. The Appendix A describes in detail how we calculate the control variables.

\section{Empirical Results}

\subsection{Short-and Long-Term Volatilities}

Table 1 shows the estimated parameters of the market volatility model. The model specification is given in Equations (1) to (3). The standard errors of the return process imply that the statistical significance is low, but it has been difficult to estimate with small errors in the literature, and these parameters do not affect our results because the main variables are volatility components. We find that the volatility-process parameters are quite significant. Particularly, given that the mean-reverting parameter of the long-term volatility component is greater than that of the short-term volatility component, we can see that the long-term component is more persistent (i.e., $\theta_{8}>\theta_{4}$ ). This is consistent with the model assumption.

Table 1. Volatility model estimation result.

\begin{tabular}{cccccccccc}
\hline $\boldsymbol{\theta}_{1}$ & $\boldsymbol{\theta}_{2}$ & $\boldsymbol{\theta}_{3}$ & $\boldsymbol{\theta}_{4}$ & $\boldsymbol{\theta}_{5}$ & $\boldsymbol{\theta}_{6}$ & $\boldsymbol{\theta}_{7}$ & $\boldsymbol{\theta}_{8}$ & $\boldsymbol{\theta}_{9}$ & $\boldsymbol{\theta}_{10}$ \\
\hline 0.0106 & -0.0813 & 0.0115 & 0.9339 & -0.0450 & 0.0600 & 0.0011 & 0.9989 & -0.0027 & 0.0298 \\
$(0.0147)$ & $(0.0724)$ & $(0.0358)$ & $(0.0092)$ & $(0.0040)$ & $(0.0064)$ & $(0.0003)$ & $(0.0004)$ & $(0.0020)$ & $(0.0034)$ \\
\hline \multicolumn{1}{c}{ Note: Standard errors are in parentheses. }
\end{tabular}

With the estimated parameters, we compute daily time-series of the short- and long-term volatility components and display them in Figure 1. Again, we can see that the long-term component is more persistent.

As described earlier, with the estimated short- and long-term components, we compute the short- and long-term factors, Fsres and Flres, respectively. Table 2 presents the summary statistics of the factors that mimic innovations in short- and long-term volatilities (Flres and Fsres) and other pricing factors such as the market (MKT), size (SMB), and value (HML) factors. The monthly volatility components are estimated as shown in Section 3.2. The monthly MKT, SMB, and HML factors are described in detail in the Appendix A. 

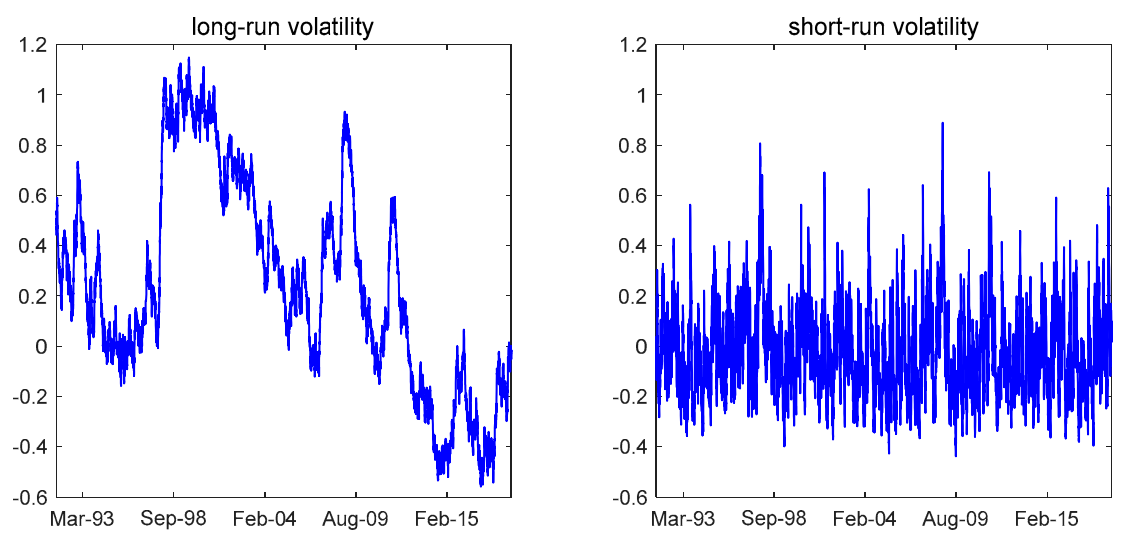

Figure 1. Daily time-series of the long- and short-term volatility components.

Table 2. Summary statistics of risk factors.

\begin{tabular}{cccccc}
\hline & Flres & Fsres & MKT & SMB & HML \\
\hline Min & -0.544 & -1.006 & -24.466 & -20.372 & -19.306 \\
Max & 0.770 & 1.739 & 41.952 & 37.037 & 21.977 \\
Mean & 0.011 & 0.032 & 0.348 & 0.430 & 0.786 \\
Std. Dev & 0.156 & 0.302 & 7.537 & 5.935 & 4.503 \\
Skewness & 0.923 & 0.669 & 0.678 & 0.521 & 0.041 \\
Kurtosis & 4.667 & 3.669 & 3.595 & 4.711 & 4.356 \\
\hline
\end{tabular}

\subsection{Portfolio Analysis}

Table 3 shows the average excess returns and the sensitivities to innovations in volatility components of the equal-weighted quintile portfolios sorted by the loadings on factors mimicking long- and short-term volatility innovations. The equal-weighted average excess returns of five portfolios are shown in the column labeled "Return". The columns labeled "Flres" and "Fsres" present the time-series average of the sensitivities to mimicking factors of these portfolios. The methodology is described in detail in Section 3.3. The "High-low" row refers to the value of the highest portfolio minus the lowest portfolio. According to each coefficient, Newey-West t-statistics [50] are reported in parentheses.

Table 3. Portfolio analysis.

\begin{tabular}{|c|c|c|c|c|c|}
\hline \multicolumn{3}{|c|}{ Panel A: Sorted on Flres } & \multicolumn{3}{|c|}{ Panel B: Sorted on Fsres } \\
\hline Portfolio & Return (\%) & Flres & Portfolio & Return $(\%)$ & Fsres \\
\hline 1-Low & $\begin{array}{l}32.78 \\
(4.08)\end{array}$ & $\begin{array}{l}-53.85 \\
(-8.14)\end{array}$ & 1-Low & $\begin{array}{l}32.75 \\
(4.08)\end{array}$ & $\begin{array}{c}-27.38 \\
(-11.99)\end{array}$ \\
\hline 2 & $\begin{array}{l}11.37 \\
(2.17)\end{array}$ & $\begin{array}{c}-15.4 \\
(-5.96)\end{array}$ & 2 & $\begin{array}{l}11.39 \\
(2.15)\end{array}$ & $\begin{array}{c}-8.56 \\
(-7.27)\end{array}$ \\
\hline 3 & $\begin{array}{c}5.61 \\
(1.25)\end{array}$ & $\begin{array}{c}2.76 \\
(1.96)\end{array}$ & 3 & $\begin{array}{c}5.68 \\
(1.19)\end{array}$ & $\begin{array}{c}0.33 \\
(0.33)\end{array}$ \\
\hline 4 & $\begin{array}{c}5.42 \\
(1.14)\end{array}$ & $\begin{array}{l}20.39 \\
(9.45)\end{array}$ & 4 & $\begin{array}{c}5.22 \\
(1.10)\end{array}$ & $\begin{array}{c}9.20 \\
(6.53)\end{array}$ \\
\hline 5-High & $\begin{array}{l}18.78 \\
(2.98)\end{array}$ & $\begin{array}{c}57.68 \\
(11.61)\end{array}$ & 5-High & $\begin{array}{l}18.90 \\
(3.26)\end{array}$ & $\begin{array}{c}28.17 \\
(10.54)\end{array}$ \\
\hline High-low & $\begin{array}{c}-14.00 \text { ** } \\
(-2.52)\end{array}$ & $\begin{array}{c}111.53 * * * \\
(10.21)\end{array}$ & High-low & $\begin{array}{c}-13.85^{* * *} \\
(-2.61)\end{array}$ & $\begin{array}{c}55.56 \text { *** } \\
(13.65)\end{array}$ \\
\hline
\end{tabular}

Note: ${ }^{* *}$ and ${ }^{* *}$ indicate significance at the $1 \%$ and $5 \%$ levels, respectively. 
Panel A reports the results of portfolios sorted by the loadings on the factor mimicking long-term volatility innovations (Flres). The average excess return decreases from $32.78 \%$ to $18.78 \%$, a spread of $14.00 \%$ per annum, which is statistically significant at the $5 \%$ level. The loading on factor Flres ranges from -53.85 to 57.68 , a spread of 111.53 . Consistent with the negative price of the long-term volatility risk found by Adrian and Rosenberg [15] in the U.S. stock market, stocks listed in the Korean market with higher sensitivities to long-term volatility have lower average returns. Long-term volatility appears to be important economically. The long-short portfolio earns an average return of $-14 \%$ per annum (t-statistics -2.52). A unit increase in sensitivity to the long-term volatility component can lead to a $0.13 \%(=-14 / 111.53)$ reduction in expected return.

Panel B reports the results of portfolios sorted by the loadings on the factor mimicking short-term volatility innovations (Fsres). Similar to the result for long-term volatility, the result in the Korean stock market also shows lower average returns with higher loadings on short-term volatility. The spread in average returns in excess of the risk-free rates between portfolios 5 and 1 is $13.85 \%$ per annum, statistically significant at the $1 \%$ level. The loading on the factor Fsres ranges from -27.38 to 28.17 , a spread of 55.56. This result is consistent with that of a study of the U.S. stock market by Adrian and Rosenberg [15]. A unit increase in sensitivity to the short-term volatility component can lead to a $0.25 \%$ $(=-13.85 / 55.56)$ reduction in the expected return.

Previous studies [51,52] indicate that investors are inclined to hedge against changes in market volatility since increases in volatility reduce the desirability of investment opportunities. Bakshi and Kapadia [53] show that investors will pay premiums for securities with high sensitivity to market volatility since such assets allow hedging against market volatility. Hence, the high-volatility-sensitive portfolio (P5) is expected to underperform the low-volatility-sensitive portfolio (P1). The negative prices of the two volatility components suggest that risk-averse investors tend to hedge the market volatility risk, regardless of whether the volatility is short- or long-term. In summary, the results show that investors are willing to pay a premium of $0.13 \%(0.25 \%)$ per annum for securities with high sensitivity to sustainable volatility (volatile volatility) to hedge for future uncertainty.

\subsection{Fama-MacBeth Regression}

The above mentioned results derived from portfolio sorts reveal that exposures to both long-and short-term volatilities are related to the average returns in the Korean stock market. In addition, the negative average returns of the long-short portfolios suggest negative prices of both the long- and short-term volatility components. In this section, the results of the Fama-MacBeth two-stage regressions are reported in Table 4 to estimate the prices of the short-and long-term volatility components, after controlling for other factors simultaneously. In panel A, we run a regression of the excess returns of the 25 portfolios sorted by size and the ratio of book-to-market equity on risk factors. We also conduct regressions at the individual-stock level, with the results reported in panel B. The method used in forming the 25 portfolios and the two-stage Fama-MacBeth regressions are elaborately described in Section 3.4. Section 3.2 provides details on the estimates of both volatility components. Other cross-sectional factors such as MKT, HML, and SMB are described in the Appendix A. In panel $\mathrm{A}$, we show the results of both the equal- and value-weighted excess returns of the 25 portfolios.

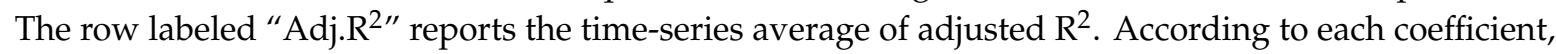
Newey-West t-statistics [50] are reported in parentheses. 
Table 4. Fama-MacBeth regressions.

\begin{tabular}{|c|c|c|c|c|c|c|c|c|}
\hline \multicolumn{9}{|c|}{ Panel A: Regression with 25 Portfolios } \\
\hline & \multicolumn{4}{|c|}{ Equal-Weight } & \multicolumn{4}{|c|}{ Value-Weight } \\
\hline Model & $\mathbf{I}$ & II & III & IV & $\mathbf{I}$ & II & III & IV \\
\hline Intercept & $\begin{array}{c}12.298 * * \\
(2.34)\end{array}$ & $\begin{array}{c}13.651 * * \\
(2.27)\end{array}$ & $\begin{array}{c}11.102^{* *} \\
(2.26)\end{array}$ & $\begin{array}{l}-0.899 \\
(-0.19)\end{array}$ & $\begin{array}{l}2.451 \\
(0.55)\end{array}$ & $\begin{array}{l}4.336 \\
(0.84) \\
\end{array}$ & $\begin{array}{l}3.571 \\
(0.85)\end{array}$ & $\begin{array}{l}-1.973 \\
(-0.46)\end{array}$ \\
\hline MKT & $\begin{array}{l}1.947 \\
(0.37)\end{array}$ & $\begin{array}{l}-2.817 \\
(-0.59)\end{array}$ & $\begin{array}{l}0.578 \\
(0.11)\end{array}$ & $\begin{array}{l}7.496 \\
(1.23)\end{array}$ & $\begin{array}{c}8.917^{* *} \\
(2.04)\end{array}$ & $\begin{array}{c}4.89 \\
(1.32)\end{array}$ & $\begin{array}{c}6.378 * \\
(1.67)\end{array}$ & $\begin{array}{l}8.396 \\
(1.53)\end{array}$ \\
\hline Flres & $\begin{array}{c}-0.500 \\
* * * \\
(-3.01)\end{array}$ & & $\begin{array}{c}-0.373 \\
* * * \\
(-2.74)\end{array}$ & $\begin{array}{c}-0.315 \\
* * * \\
(-3.02)\end{array}$ & $\begin{array}{c}-0.362 \\
* * * \\
(-2.85)\end{array}$ & & $\begin{array}{c}-0.308 \\
* * * \\
(-2.80)\end{array}$ & $\begin{array}{c}-0.287 \\
* * * \\
(-3.96)\end{array}$ \\
\hline Fsres & & $\begin{array}{c}-0.468 * \\
(-1.65)\end{array}$ & $\begin{array}{c}-0.467 * \\
(-1.86)\end{array}$ & $\begin{array}{c}-0.556^{* *} \\
(-2.32)\end{array}$ & & $\begin{array}{c}-0.500 * * \\
(-2.22)\end{array}$ & $\begin{array}{c}-0.521^{* *} \\
(-2.34)\end{array}$ & $\begin{array}{c}-0.601 \\
* * * \\
(-2.62)\end{array}$ \\
\hline HML & & & & $\begin{array}{c}11.711^{* * *} \\
(3.30)\end{array}$ & & & & $\begin{array}{c}9.025^{* * *} \\
(2.87)\end{array}$ \\
\hline $\mathrm{SMB}$ & & & & $\begin{array}{c}10.079 * * * \\
(2.61)\end{array}$ & & & & $\begin{array}{l}4.761 \\
(1.63)\end{array}$ \\
\hline Adj. $\mathrm{R}^{2}$ & $\begin{array}{c}0.271^{* * *} \\
(8.18)\end{array}$ & $\begin{array}{c}0.251 * * * \\
(7.41)\end{array}$ & $\begin{array}{c}0.344^{* * *} \\
(9.77)\end{array}$ & $\begin{array}{c}0.498^{* * *} \\
(15.52)\end{array}$ & $\begin{array}{c}0.258^{* * *} \\
(8.12)\end{array}$ & $\begin{array}{c}0.233^{* * *} \\
(6.60)\end{array}$ & $\begin{array}{c}0.314^{* * *} \\
(9.05)\end{array}$ & $\begin{array}{c}0.442^{* * *} \\
(14.22)\end{array}$ \\
\hline \multicolumn{9}{|c|}{ Panel B: Regression with Individual Stocks } \\
\hline Model & \multicolumn{2}{|c|}{ I } & \multicolumn{2}{|c|}{ II } & \multicolumn{2}{|c|}{ III } & \multicolumn{2}{|c|}{ IV } \\
\hline Intercept & \multicolumn{2}{|c|}{$\begin{array}{c}8.635 * * \\
(2.16)\end{array}$} & \multicolumn{2}{|c|}{$\begin{array}{c}7.860 * \\
(1.96)\end{array}$} & \multicolumn{2}{|c|}{$\begin{array}{c}7.758^{* *} \\
(1.98)\end{array}$} & \multicolumn{2}{|c|}{$\begin{array}{l}3.557 \\
(1.02)\end{array}$} \\
\hline MKT & \multicolumn{2}{|c|}{$\begin{array}{c}7.611^{* *} \\
(2.32)\end{array}$} & \multicolumn{2}{|c|}{$\begin{array}{c}7.202 * * \\
(2.52)\end{array}$} & \multicolumn{2}{|c|}{$\begin{array}{c}7.740 * * \\
(2.39)\end{array}$} & \multicolumn{2}{|c|}{$\begin{array}{c}8.473^{* *} \\
(2.37)\end{array}$} \\
\hline Flres & \multicolumn{2}{|c|}{$\begin{array}{c}-0.125^{* *} \\
(-2.10)\end{array}$} & & & \multicolumn{2}{|c|}{$\begin{array}{c}-0.111^{* *} \\
(-2.02)\end{array}$} & \multicolumn{2}{|c|}{$\begin{array}{c}-0.095 * \\
(-1.75)\end{array}$} \\
\hline Fsres & & & \multicolumn{2}{|c|}{$\begin{array}{c}-0.361 \text { *** } \\
(-3.10)\end{array}$} & \multicolumn{2}{|c|}{$\begin{array}{c}-0.340 * * * \\
(-3.04)\end{array}$} & \multicolumn{2}{|c|}{$\begin{array}{c}-0.332 * * * \\
(-3.07)\end{array}$} \\
\hline HML & & & & & & & \multicolumn{2}{|c|}{$\begin{array}{l}2.305 \\
(1.65)\end{array}$} \\
\hline $\mathrm{SMB}$ & & & & & & & \multicolumn{2}{|c|}{$\begin{array}{c}3.853^{* *} \\
(2.26)\end{array}$} \\
\hline Adj. $R^{2}$ & \multicolumn{2}{|c|}{$\begin{array}{c}0.065^{* * *} \\
(5.23)\end{array}$} & \multicolumn{2}{|c|}{$\begin{array}{c}0.065^{* * *} \\
(4.55)\end{array}$} & \multicolumn{2}{|c|}{$\begin{array}{c}0.083^{* * *} \\
(5.44)\end{array}$} & \multicolumn{2}{|c|}{$\begin{array}{c}0.109^{* * *} \\
(6.23)\end{array}$} \\
\hline
\end{tabular}

Note: ${ }^{* * *}, * *$, and ${ }^{*}$ indicate significance at the $1 \%, 5 \%$, and $10 \%$ levels, respectively.

Panel A shows the results of regressions in the case where the portfolio is the base asset. Models I and II report risk prices when the short- term and long-term volatility components are set separately. Long-term volatility has a negative risk price, significant at the $1 \%$ level in both schemes. In the case where the equal-weighted excess returns of the 25 portfolios are the base asset, the risk price of the long-term component of $-0.5 \%$ implies that a stock with a long-term beta of unity requires a 5-basis-point lower return than a stock with zero sensitivity to the long-term component. The result is the same as in the case where the value-weighted excess returns of the 25 portfolios are the base asset; however, the magnitude of the price of the long-term component is slightly smaller. The short-term volatility component also has a negative risk price, significant in both schemes. Model III (wherein both components enter simultaneously) reports the same results for both schemes, suggesting that aggregate short-and long-term components are priced separately in the cross-section. Model IV, controlling for 
the size and value effects of the Fama-French [22] three-factor model, further confirms the explanatory power of the two volatility components in the cross-section stock returns of Korean market. Including these factors only strengthens the risk price of the short-term volatility component and slightly weakens that of the long-term component. These risk prices remain significantly negative. The negative risk prices imply that stocks with high exposure to both the short-and long-term volatilities innovations earn low returns. This is economically significant since such stocks provide useful hedges for risk-averse investors who dislike high volatility risk. The higher demand for stocks with high sensitivities to volatilities increases their prices and decreases their expected returns.

Panel B shows the results of regressions in the case where individual stocks are the base asset. The results confirm that both volatility components are significantly priced factors and both components have negative risk prices. In addition, these impacts are economically important. The price of the long-term volatility component is -0.095 . This indicates that a two-standard-deviation increase across stocks exposed to the long-term component $\left(\beta_{\text {Flres }}\right)$ is associated with a $1.27 \%(=-0.095 \times 2 \times 6.69)$ decrease in the expected return per annum. To evaluate the economic importance, we use the time-series average of the cross sectional standard deviations of $\beta_{\text {Flres }}$ estimated in the first stage of the two-stage Fama-MacBeth regressions based on Equation (8), specifically, 6.69. Similarly, the price of the short-term component is -0.332 , implying that the expected return decreases by $2.13 \%$ per annum $(=-0.332 \times 2 \times 3.21)$ with a two-standard-deviation increase across stocks exposed to the short-term component $\left(\beta_{\text {Fsres }}\right)$. The time-series average of the cross-sectional standard deviations of $\beta_{\text {Fsres }}$ is 3.21 .

The results in panels A and B are similar. They show that after controlling for other cross-sectional effects, both volatility components have explanatory power in the asset-pricing in the Korean market. Moreover, the risk prices are significantly negative, consistent with the results found in the U.S. stock market by Adrian and Rosenberg [15].

\section{Robustness}

In this section, we re-examine the sample of stocks listed in the KOSPI market. Most researchers who study the Korean financial market focus on stocks listed in Korea's main trading board, that is, the KOSPI market, because of the high level of liquidity. The low transaction costs of the liquid KOSPI market help minimize biases. By contrast, in the KOSDAQ market, retail investors are the majority. Hence, the results might be affected by the noise of mispricing by traders (e.g., individual investors) and the characteristics of KOSDAQ stocks (e.g., low prices and small capitalization). High market volatility and the absence of institutional investors are also considered issues with the KOSDAQ market. Therefore, we follow the same methodology but exclude stocks listed in the KOSDAQ market.

Table 5 shows the average returns in excess of the risk-free rate and the loadings on volatility component innovations of the equal-weighted quintile portfolios sorted by the loadings on factors mimicking long-and short-term volatility innovations. The results show that in the KOSPI, stocks with higher sensitivities to both long- and short-term volatility have lower average returns, consistent with the results based on the entire Korean stock market, including stocks listed in both the KOSPI and KOSDAQ.

After controlling for size and value effects by running Fama-MacBeth two-stage regressions, (shown in Table 6), the risk prices of both volatility components remain significantly negative in both cases, as shown in panels A and B. The price of the long-term volatility component is -0.109 , reported in Panel B. This indicates that a two-standard-deviation increase across stocks exposed to the long-term component $\left(\beta_{\text {Flres }}\right)$ is associated with a $1.54 \%(=-0.109 \times 2 \times 7.06)$ decrease in the expected return per annum. With the time-series average of the cross-sectional standard deviation of $\beta_{\text {Fsres }}$ (3.26), the corresponding reduction in the expected returns is $2.35 \%(=-0.361 \times 2 \times 3.26)$. 
Table 5. Portfolio analysis: stocks listed in the KOSPI.

\begin{tabular}{|c|c|c|c|c|c|}
\hline \multicolumn{3}{|c|}{ Panel A: Sorted on Flres } & \multicolumn{3}{|c|}{ Panel B: Sorted on Fsres } \\
\hline Portfolio & Return & Flres & Portfolio & Return & Fsres \\
\hline 1-Low & $\begin{array}{l}26.61 \\
(4.50)\end{array}$ & $\begin{array}{c}-44.39 \\
(-11.05)\end{array}$ & 1-Low & $\begin{array}{l}28.13 \\
(4.34)\end{array}$ & $\begin{array}{c}-22.12 \\
(-12.82)\end{array}$ \\
\hline 2 & $\begin{array}{l}10.11 \\
(2.00)\end{array}$ & $\begin{array}{l}-13.35 \\
(-6.93)\end{array}$ & 2 & $\begin{array}{l}10.72 \\
(2.01)\end{array}$ & $\begin{array}{l}-7.71 \\
(-8.21)\end{array}$ \\
\hline 3 & $\begin{array}{c}6.66 \\
(1.36)\end{array}$ & $\begin{array}{c}1.41 \\
(0.95)\end{array}$ & 3 & $\begin{array}{c}6.61 \\
(1.36)\end{array}$ & $\begin{array}{l}-1.05 \\
(-1.58)\end{array}$ \\
\hline 4 & $\begin{array}{c}7.39 \\
(1.40)\end{array}$ & $\begin{array}{l}16.07 \\
(9.31)\end{array}$ & 4 & $\begin{array}{c}7.48 \\
(1.55)\end{array}$ & $\begin{array}{c}5.40 \\
(8.54)\end{array}$ \\
\hline 5-High & $\begin{array}{l}19.49 \\
(3.22)\end{array}$ & $\begin{array}{c}47.09 \\
(14.29)\end{array}$ & 5-High & $\begin{array}{l}17.31 \\
(3.10)\end{array}$ & $\begin{array}{c}19.02 \\
(19.93)\end{array}$ \\
\hline High-low & $\begin{array}{l}-7.12 * * \\
(-2.19)\end{array}$ & $\begin{array}{c}91.48^{* * *} \\
(14.13)\end{array}$ & High-low & $\begin{array}{c}-10.82 * * * \\
(-3.43)\end{array}$ & $\begin{array}{c}41.14^{* * * *} \\
(18.96)\end{array}$ \\
\hline
\end{tabular}

Note: ${ }^{* * *}$ and ${ }^{* *}$ indicate significance at the $1 \%$ and $5 \%$ levels, respectively.

Table 6. Fama-MacBeth regressions: including the stocks listed in the KOSPI.

\begin{tabular}{|c|c|c|c|c|c|c|c|c|}
\hline \multicolumn{9}{|c|}{ Panel A: Regression with 25 Portfolios } \\
\hline & \multicolumn{4}{|c|}{ Equal-Weight } & \multicolumn{4}{|c|}{ Value-Weight } \\
\hline Model & I & II & III & IV & I & II & III & IV \\
\hline Intercept & $\begin{array}{l}6.912 \\
(1.47)\end{array}$ & $\begin{array}{l}5.969 \\
(1.23)\end{array}$ & $\begin{array}{l}3.768 \\
(0.81)\end{array}$ & $\begin{array}{l}-3.824 \\
(-0.90)\end{array}$ & $\begin{array}{l}0.735 \\
(0.15)\end{array}$ & $\begin{array}{l}0.812 \\
(0.16)\end{array}$ & $\begin{array}{l}1.298 \\
(0.27)\end{array}$ & $\begin{array}{l}-3.186 \\
(-0.81)\end{array}$ \\
\hline MKT & $\begin{array}{l}2.938 \\
(0.66)\end{array}$ & $\begin{array}{l}3.107 \\
(0.73)\end{array}$ & $\begin{array}{l}4.184 \\
(0.97)\end{array}$ & $\begin{array}{c}8.529 * \\
(1.84)\end{array}$ & $\begin{array}{c}9.573^{* * *} \\
(2.65)\end{array}$ & $\begin{array}{c}8.012^{* *} \\
(2.34)\end{array}$ & $\begin{array}{c}7.641^{* *} \\
(2.24)\end{array}$ & $\begin{array}{c}9.796^{* *} \\
(2.24)\end{array}$ \\
\hline Flres & $\begin{array}{c}-0.300 * * \\
(-2.01)\end{array}$ & & $\begin{array}{c}-0.286^{* *} \\
(-2.38)\end{array}$ & $\begin{array}{c}-0.280 \\
* * * \\
(-2.78)\end{array}$ & $\begin{array}{c}-0.283 \\
* * * \\
(-2.64)\end{array}$ & & $\begin{array}{c}-0.274 \\
* * * \\
(-2.95)\end{array}$ & $\begin{array}{c}-0.207 \\
* * * \\
(-2.64)\end{array}$ \\
\hline Fsres & & $\begin{array}{c}-0.777^{* *} \\
(-2.29)\end{array}$ & $\begin{array}{c}-0.730 * * \\
(-2.18)\end{array}$ & $\begin{array}{c}-0.561 \text { ** } \\
(-2.14)\end{array}$ & & $\begin{array}{c}-0.625^{* *} \\
(-2.49)\end{array}$ & $\begin{array}{c}-0.582 \text { ** } \\
(-2.41)\end{array}$ & $\begin{array}{c}-0.425^{* *} \\
(-2.36)\end{array}$ \\
\hline$H M L$ & & & & $\begin{array}{c}11.978^{* * *} \\
(3.44)\end{array}$ & & & & $\begin{array}{c}7.853 * * * \\
(2.76)\end{array}$ \\
\hline$S M B$ & & & & $\begin{array}{c}8.845^{* * *} \\
(2.74)\end{array}$ & & & & $\begin{array}{l}4.222 \\
(1.46)\end{array}$ \\
\hline Adj. $R^{2}$ & $\begin{array}{c}0.177^{* * *} \\
(6.03)\end{array}$ & $\begin{array}{c}0.219 * * * \\
(7.17)\end{array}$ & $\begin{array}{c}0.249 * * * \\
(7.71)\end{array}$ & $\begin{array}{c}0.400 \text { *** } \\
(12.11)\end{array}$ & $\begin{array}{c}0.160 * * * \\
(5.38)\end{array}$ & $\begin{array}{c}0.174^{* * *} \\
(5.28)\end{array}$ & $\begin{array}{c}0.214^{* * *} \\
(6.26)\end{array}$ & $\begin{array}{c}0.355^{* * *} \\
(9.75)\end{array}$ \\
\hline \multicolumn{9}{|c|}{ Panel B: Regression with Individual Stocks } \\
\hline Model & \multicolumn{2}{|c|}{ I } & \multicolumn{2}{|c|}{ II } & \multicolumn{2}{|c|}{ III } & \multicolumn{2}{|c|}{ IV } \\
\hline Intercept & \multicolumn{2}{|c|}{$\begin{array}{c}7.154 * \\
(1.75)\end{array}$} & \multicolumn{2}{|c|}{$\begin{array}{l}6.573 \\
(1.62)\end{array}$} & \multicolumn{2}{|c|}{$\begin{array}{l}6.485 \\
(1.62)\end{array}$} & \multicolumn{2}{|c|}{$\begin{array}{l}1.242 \\
(0.36)\end{array}$} \\
\hline$M K T$ & \multicolumn{2}{|c|}{$\begin{array}{c}7.935^{* * *} \\
(2.97)\end{array}$} & \multicolumn{2}{|c|}{$\begin{array}{c}7.825^{* * *} \\
(3.09)\end{array}$} & \multicolumn{2}{|c|}{$\begin{array}{c}8.167^{* * *} \\
(3.02)\end{array}$} & \multicolumn{2}{|c|}{$\begin{array}{c}9.078 * * * \\
(2.79)\end{array}$} \\
\hline Flres & \multicolumn{2}{|c|}{$\begin{array}{c}-0.136^{* *} \\
(-2.21)\end{array}$} & & & \multicolumn{2}{|c|}{$\begin{array}{c}-0.121 * * \\
(-2.10)\end{array}$} & \multicolumn{2}{|c|}{$\begin{array}{c}-0.109 * \\
(-1.86)\end{array}$} \\
\hline Fsres & & & \multicolumn{2}{|c|}{$\begin{array}{c}-0.358^{* * *} \\
(-3.33)\end{array}$} & \multicolumn{2}{|c|}{$\begin{array}{c}-0.351 \text { *** } \\
(-3.38)\end{array}$} & \multicolumn{2}{|c|}{$\begin{array}{c}-0.361^{* * *} \\
(-3.40)\end{array}$} \\
\hline$H M L$ & & & & & & & \multicolumn{2}{|c|}{$\begin{array}{c}3.474^{* *} \\
(2.35)\end{array}$} \\
\hline$S M B$ & & & & & & & \multicolumn{2}{|c|}{$\begin{array}{c}4.140^{* *} \\
(2.34)\end{array}$} \\
\hline Adj. $R^{2}$ & \multicolumn{2}{|c|}{$\begin{array}{c}0.069^{* * *} \\
(6.24)\end{array}$} & \multicolumn{2}{|c|}{$\begin{array}{c}0.071^{* * *} \\
(5.27)\end{array}$} & \multicolumn{2}{|c|}{$\begin{array}{c}0.092^{* * *} \\
(6.71)\end{array}$} & \multicolumn{2}{|c|}{$\begin{array}{c}0.128^{* * *} \\
(8.45)\end{array}$} \\
\hline
\end{tabular}

Note: ${ }^{* * *}, * *$, and ${ }^{*}$ indicate significance at the $1 \%, 5 \%$, and $10 \%$ levels, respectively. 


\section{Conclusions}

This study explores the relationship between the cross-section of stock returns and market volatility by decomposing volatility into short-and long-term components in the Korean stock market. Our study provides several important findings. After controlling for market, size, and value factors of the Fama-French model, we find that both short- and long-term volatility components are negatively priced in the Korean stock market. Furthermore, our results show that stocks with higher sensitivities to long-term volatility innovation have lower average returns by approximately $14 \%$, compared with stocks having lower sensitivities.

In summary, our study provides evidence of negative price of volatility factor in the stock market to address previous controversial results. Besides, our result implies that investors are willing to pay a unit premium of $0.13 \%$ per annum for stocks with high sensitivity to sustainable volatility, as they hedge against future market uncertainties.

This study uses only one model specification suggested by Adrian and Rosenberg [15] to decompose market volatility components. The alternative specifications, such as the Exponential Generalized Autoregressive Conditional Heteroskedasticity model of Nelson [54], and the GARCH-GJR model of Glosten et al. [39] should be used to estimate volatility factors to ensure that the significance of the market volatility components is robust to many volatility model specifications used in the pricing tests. Future research should consider this limitation.

Author Contributions: The authors' contributions are as follows, T.T.T.T.: Software, formal analysis, investigation, data curation, writing, and preparation of the original draft; J.K.: Methodology, validation, writing, review and editing, supervision, and project administration.

Funding: This research received no external funding.

Acknowledgments: We thank the anonymous referees for their valuable suggestions.

Conflicts of Interest: The authors declare no conflict of interest.

\section{Appendix A}

The market factor, MKT, is the value-weighted return of all stocks listed in both the KOSPI and KOSDAQ markets minus the risk-free rate of return. SMB and HML are constructed using the six value-weighted portfolios formed based on the size and book-to-market equity at the end of June of year T, following Fama and French [22]. Based on the median KOSPI market equity (ME) at the end of June of year $T$, the sample stocks are divided into Small (S) group with stocks whose market equity is less than the median value and Big (B) group with the remaining stocks. Based on value of the 30th and 70th KOSPI percentiles of the book-to-market equity (BE/ME) ratio, the sample stocks are divided into High (H), Medium (M), and Low (L) groups. BE/ME is the book equity for the last fiscal year end in T-1 divided by the market equity for December of year T-1. Firms with negative BE/ME are excluded. The monthly value-weighted returns of these six portfolios are calculated from July of year $\mathrm{T}$ to June of year T +1 . Each month, SMB (Small Minus Big) is the difference between the average return of three small portfolios $(\mathrm{S} / \mathrm{L}, \mathrm{S} / \mathrm{M}, \mathrm{S} / \mathrm{H})$ and the average return of three big portfolios $(\mathrm{B} / \mathrm{L}, \mathrm{B} / \mathrm{M}, \mathrm{B} / \mathrm{H})$. HML (High Minus Low) is the difference between the average return of two high BE/ME portfolios $(\mathrm{S} / \mathrm{H}, \mathrm{B} / \mathrm{H})$ and the average return of two low $\mathrm{BE} / \mathrm{ME}$ portfolios $(\mathrm{S} / \mathrm{L}, \mathrm{B} / \mathrm{L})$.

\section{References}

1. Sharpe, W.F. Capital Asset Prices: A Theory of Market Equilibrium Under Conditions of Risk. J. Financ. 1964, $19,425-442$.

2. Lintner, J. The Valuation of Risk Assets and the Selection of Risky Investments in Stock Portfolios and Capital Budgets. Rev. Econ. Stat. 1965, 47, 13-37. [CrossRef]

3. Ang, A.; Hodrick, R.J.; Xing, Y.; Zhang, X. The Cross-Section of Volatility and Expected Returns. J. Financ. 2006, 61, 259-299. [CrossRef]

4. Frazzini, A.; Pedersen, L.H. Betting against beta. J. Financ. Econ. 2014, 111, 1-25. [CrossRef] 
5. Engle, R.F.; Rosenberg, J.V. Testing the Volatility Term Structure Using Option Hedging Criteria. JOD 2000, 8, 10-28. [CrossRef]

6. Bollerslev, T.; Zhou, H. Estimating stochastic volatility diffusion using conditional moments of integrated volatility. J. Econom. 2002, 109, 33-65. [CrossRef]

7. Alizadeh, S.; Brandt, M.W.; Diebold, F.X. Range-Based Estimation of Stochastic Volatility Models. J. Financ. 2002, 57, 1047-1091. [CrossRef]

8. Chacko, G.; Viceira, L.M. Spectral GMM estimation of continuous-time processes. J. Econom. 2003, 116, 259-292. [CrossRef]

9. Chernov, M.; Ronald Gallant, A.; Ghysels, E.; Tauchen, G. Alternative models for stock price dynamics. J. Econom. 2003, 116, 225-257. [CrossRef]

10. Maheu, J. Can GARCH Models Capture Long-Range Dependence? Stud. Nonlinear Dyn. Econom. 2005, 9. [CrossRef]

11. Brandt, M.W.; Jones, C.S. Volatility Forecasting With Range-Based EGARCH Models. J. Bus. Econ. Stat. 2006, 24, 470-486. [CrossRef]

12. Speight, A.E.H.; McMillan, D.G.; Gwilym, O. ap Intra-day volatility components in FTSE-100 stock index futures. J. Futures Mark. 2000, 20, 425-444. [CrossRef]

13. Christoffersen, P.; Jacobs, K.; Ornthanalai, C.; Wang, Y. Option valuation with long-run and short-run volatility components. J. Financ. Econ. 2008, 90, 272-297. [CrossRef]

14. Ané, T. Short and long term components of volatility in Hong Kong stock returns. Appl. Financ. Econ. 2006, 16, 439-460. [CrossRef]

15. Adrian, T.; Rosenberg, J. Stock returns and volatility: Pricing the short-run and long-run components of market risk. J. Financ. 2008, 63, 2997-3030. [CrossRef]

16. Yang, Y.; Copeland, L. The cross-sectional risk premium of decomposed market volatility in UK stock market. Open J. Soc. Sci. 2014, 2, 30. [CrossRef]

17. Guo, H.; Neely, C.J. Investigating the intertemporal risk-return relation in international stock markets with the component GARCH model. Econ. Lett. 2008, 99, 371-374. [CrossRef]

18. Zhu, J. Pricing volatility of stock returns with volatile and persistent components. Financ. Mark. Portf. Manag. 2009, 23, 243-269. [CrossRef]

19. Park, S.; Jung, H. The Effect of Managerial Ability on Future Stock Price Crash Risk: Evidence from Korea. Sustainability 2017, 9, 2334. [CrossRef]

20. Merton, R.C. An intertemporal capital asset pricing model. Econom. J. Econom. Soc. 1973, 867-887. [CrossRef]

21. Fama, E.F.; MacBeth, J.D. Risk, Return, and Equilibrium: Empirical Tests. J. Political Econ. 1973, 81, $607-636$. [CrossRef]

22. Fama, E.F.; French, K.R. Common risk factors in the returns on stocks and bonds. J. Financ. Econ. 1993, 33, 3-56. [CrossRef]

23. Altman, E.I.; Schwartz, R.A. Common Stock Price Volatility Measures and Patterns. J. Financ. Quant. Anal. 1970, 4, 603-625. [CrossRef]

24. Pinches, G.E.; Kinney, W.R. The measurement of the volatility of common stock prices. J. Financ. 1971, 26, 119-125. [CrossRef]

25. Black, F.; Scholes, M. The Pricing of Options and Corporate Liabilities. J. Political Econ. 1973, 81, $637-654$. [CrossRef]

26. Merton, R.C. Theory of Rational Option Pricing. Bell J. Econ. Manag. Sci. 1973, 4, 141. [CrossRef]

27. French, K.R.; Schwert, G.W.; Stambaugh, R.F. Expected stock returns and volatility. J. Financ. Econ. 1987, 19, 3-29. [CrossRef]

28. Engle, R.F.; Lilien, D.M.; Robins, R.P. Estimating Time Varying Risk Premia in the Term Structure: The Arch-M Model. Econometrica 1987, 55, 391. [CrossRef]

29. Goyal, A.; Saretto, A. Cross-section of option returns and volatility. J. Financ. Econ. 2009, 94, 310-326. [CrossRef]

30. Chou, R.Y. Volatility persistence and stock valuations: Some empirical evidence using garch. J. Appl. Econ. 1988, 3, 279-294. [CrossRef]

31. Campbell, J.Y.; Hentschel, L. No news is good news. J. Financ. Econ. 1992, 31, 281-318. [CrossRef]

32. Ghysels, E.; Santa-Clara, P.; Valkanov, R. There is a risk-return trade-off after all. J. Financ. Econ. 2005, 76, 509-548. [CrossRef] 
33. Guo, H.; Whitelaw, R.F. Uncovering the Risk-Return Relation in the Stock Market. J. Financ. 2006, 61, 1433-1463. [CrossRef]

34. Sehgal, S.; Garg, V.; Deisting, F. Relationship between cross sectional volatility and stock returns: Evidence from India. Invest. Manag. Financ. Innov. 2012, 9, 91-100.

35. Breen, W.; Glosten, L.R.; Jagannathan, R. Economic Significance of Predictable Variations in Stock Index Returns. J. Financ. 1989, 44, 1177-1189. [CrossRef]

36. Turner, C.M.; Startz, R.; Nelson, C.R. A Markov model of heteroskedasticity, risk, and learning in the stock market. J. Financ. Econ. 1989, 25, 3-22. [CrossRef]

37. Baillie, R.T.; DeGennaro, R.P. Stock Returns and Volatility. J. Financ. Quant. Anal. 1990, 25, 203. [CrossRef]

38. Chou, R.; Engle, R.F.; Kane, A. Measuring risk aversion from excess returns on a stock index. J. Econom. 1992, 52, 201-224. [CrossRef]

39. Glosten, L.R.; Jagannathan, R.; Runkle, D.E. On the Relation between the Expected Value and the Volatility of the Nominal Excess Return on Stocks. J. Financ. 1993, 48, 1779-1801. [CrossRef]

40. Da, Z.; Schaumburg, E. The Pricing of Volatility Risk Across Asset Classes; Unpublished Working Paper; University of Notre Dame: Notre Dame, IN, USA; Federal Reserve Bank of New York: New York, NY, USA, 2011.

41. Cremers, M.; Halling, M.; Weinbaum, D. Aggregate jump and volatility risk in the cross-section of stock returns. J. Financ. 2015, 70, 577-614. [CrossRef]

42. Sehgal, S.; Garg, V. Cross-sectional Volatility and Stock Returns: Evidence for Emerging Markets. Vikalpa 2016, 41, 234-246. [CrossRef]

43. Dimitriou, D.; Simos, T. The relationship between stock returns and volatility in the seventeen largest international stock markets: A semi-parametric approach. Mod. Econ. 2011, 1, 1-8. [CrossRef]

44. Lee, C.F.; Chen, G.; Rui, O.M. Stock Returns and Volatility on China's Stock Markets. J. Financ. Res. 2001, 24, 523-543. [CrossRef]

45. De Santis, G.; Imrohoroğlu, S. Stock returns and volatility in emerging financial markets. J. Int. Money Financ. 1997, 16, 561-579. [CrossRef]

46. Shin, J. Stock returns and volatility in emerging stock markets. Int. J. Bus. Econ. 2005, 4, 31-43.

47. Chiang, T.C.; Doong, S.-C. Empirical Analysis of Stock Returns and Volatility: Evidence from Seven Asian Stock Markets Based on TAR-GARCH Model. Rev. Quant. Financ. Account. 2001, 17, 301-318. [CrossRef]

48. Xu, X.; Taylor, S.J. The Term Structure of Volatility Implied by Foreign Exchange Options. J. Financ. Quant. Anal. 1994, 29, 57-74. [CrossRef]

49. Bates, D.S. Post-' 87 crash fears in the S\&P 500 futures option market. J. Econom. 2000, 94, 181-238.

50. Newey, W.K.; West, K.D. A Simple, Positive Semi-Definite, Heteroskedasticity and Autocorrelation Consistent Covariance Matrix. Econometrica 1987, 55, 703-708. [CrossRef]

51. Campbell, J.Y. Understanding risk and return. J. Political Econ. 1996, 104, 298-345. [CrossRef]

52. Chen, J.S. Intertemporal CAPM and the Cross-Section of Stock Returns; Unpublished Working Paper; University of Southern California: Los Angeles, CA, USA, 2003.

53. Bakshi, G.; Kapadia, N. Volatility Risk Premiums Embedded in Individual Equity Options. J. Deriv. 2003, 11, 45. [CrossRef]

54. Nelson, D.B. Conditional Heteroskedasticity in Asset Returns: A New Approach. Econometrica 1991, 59, 347-370. [CrossRef]

(C) 2019 by the authors. Licensee MDPI, Basel, Switzerland. This article is an open access article distributed under the terms and conditions of the Creative Commons Attribution (CC BY) license (http://creativecommons.org/licenses/by/4.0/). 